\title{
Cervical Vertebra
}

National Cancer Institute

\section{Source}

National Cancer Institute. Cervical Vertebra. NCI Thesaurus. Code C12693.

Any one of the seven vertebrae that start with C1, connecting the skull to the spine, and ends with C7, which joins the cervical with the thoracic spine. 